\title{
Primary Vaginal Clear Cell Adenocarcinoma: Case Report with Literature
} Review

\author{
Puja Chatterjee $^{1 *}$, Dipanwita Banerjee ${ }^{1}$, Manisha Vernekar ${ }^{1}$, Ranajit Mandal ${ }^{1}$
}

${ }^{1}$ Department of Gynecological Oncology, Chittaranjan National Cancer, Kolkata, West Bengal, India

DOI: $10.36347 /$ simcr.2021.v09i04.024

| Received: 27.02.2021 | Accepted: 18.04.2021 | Published: 26.04.2021

*Corresponding author: Puja Chatterjee

\section{Abstract}

Very few cases of Primary Vaginal Clear cell Adenocarcinoma (PVCAA) have been reported in literature. A multiparous lady aged 52 years presented with bleeding per vaginum for 1 week. On examination $3 \times 3 \mathrm{~cm}$ ulceroproliferative growth involving lower third with subvaginal extension seen. On colposcopy cervix was normal. The uterus and ovaries were normal on imaging. Biopsy from the mass revealed Clear Cell carcinoma. She underwent radical vaginectomy, distal urethral resection(approx $3 \mathrm{~cm}$ ), bilateral groin node dissection and lotus flap reconstruction of defect. Histopathology showed Clear Cell Carcinoma of vagina, Stage III. Adjuvant chemotherapy with cisplatin and paclitaxel 3 weekly for 6 cycles was followed by adjuvant External Beam Radiotherapy. Patient had presented with occasional involuntary dribbling of urine following the surgery which was managed with foleys catheterisation. The incontinence resolved without any intervention one month following radiotherapy. The patient has been recurrence free for past 3 years. The tumour board faced difficulty in taking decisions due to dearth of reported cases and consensus guidelines, prompting the authors to report the case.

Keywords: Vaginal cancer, vulvectomy, radiotherapy, chemotherapy, clear cell adenocarcinoma.

Copyright $\odot 2021$ The Author(s): This is an open-access article distributed under the terms of the Creative Commons Attribution 4.0 International License (CC BY-NC 4.0) which permits unrestricted use, distribution, and reproduction in any medium for non-commercial use provided the original author and source are credited.

\section{INTRODUCTION}

Primary Vaginal Clear Cell Adenocarcinoma (PVCCA), also known as mesonephroid cancer, has been historically linked to Diethylstilbesterol (DES). It accounts for $5-10 \%$ of primary vaginal cancers. It has a bimodal age distribution: $22 \mathrm{yrs}$ in those associated with DES, but also seen in 55year old with no such history. There are cases reported in the literature where PVCAA has been associated with pelvic endometriosis [1]. PVCCA most commonly involves the anterior wall of the upper third of vagina, corresponding to the most frequent site of adenosis, with which it has been associated [2].

\section{CASE REPORT/CASE PRESENTATION}

A 52-year-old multiparous $\left(\mathrm{P}_{2+0+0+2}\right)$ lady presented with burning micturition and vaginal bleeding for a week. She had no history of menstrual irregularities, dysmenorrhoea, previous bad obstetric history or miscarriages. She had moderate pallor, Eastern Cooperative Oncology Group (ECOG) Performance Status of 1 , with no comorbidities. No clinical supraclavicular, axillary or inguinal lymph nodes were noted. There was no calf tenderness.

Genital examination revealed a $3 \times 3 \mathrm{~cm}$ ulceroproliferative growth involving lower $1 / 3^{\text {rd }}$ of anterior vagina, clitoris with clinical involvement of the subvaginal tissue. Clitoris was also involved (Figure-1). No palpable inguinal lymph nodes were noted. No mass was palpable abdominally. On per speculum examination, cervix was healthy. Bimanual examination revealed a normal sized uterus with no adnexal mass. Per rectal examination was normal. Colposcopy examination of the cervix was adequate and swede score of 2 with no acetowhite changes. Biopsy from the mass showed clear cell adenocarcinoma.

Contrast enhanced MRI pelvis revealed a lobulated heterogeneous mass lesion involving the distal vagina. The lesion, measuring $3.4 \times 2.4 \mathrm{~cm}$, appeared hypointense on $\mathrm{T} 1$ and hyperintense on T2weighted images. It involved the distal urethral orifice with approximate $2 \mathrm{~cm}$ distance from the bladder neck or the interna. Enlarged inguinal lymph nodes were seen on the left side, the largest measuring $1.5 \mathrm{~cm}$. No pelvic lymphadenopathy. Uterus, ovaries, and 
urinary bladder were normal. A contrast-enhanced computed tomography thorax and whole abdomen was normal. Cystoscopy revealed that the urethral meatus was involved but the urinary bladder and rest of the urethra was uninvolved. Ultrasound guided Fine Needle Aspiration Cytology (FNAC) from the inguinal nodes was inconclusive.

The case was presented to the tumour board and decision for radical vulvectomy with excision of distal vagina with inguinal lymphadenectomy was taken. In case the patient has urinary incontinence after excision of distal urethra, a second procedure for urinary diversion would be planned.

She underwent radical vulvectomy, distal vaginectomy, resection of distal urethra $(\sim 3 \mathrm{~cm})$ with bilateral inguinal lymphadenectomy and lotus flap reconstruction of the defect (Figure-2). Intraoperative and postoperative period was uneventful (Figure-3). However, she developed continuous urinary incontinence which was assumed to be due to intrinsic sphincter deficiency following distal urethral resection. On urology consultation, it was planned that a second surgery may be needed after completion of adjuvant treatment.

Histopathological examination revealed invasive moderately differentiated adenocarcinoma with clear cell changes. Tubular and glandular architectural pattern, with cells having abundant clear cytoplasm, vesicular chromatin, hob-nailing seen. Tumour free margin was $2 \mathrm{~mm}$. Lympho-vascular emboli seen but no perineural invasion seen. Right sided inguinal node $(0 / 13)$ showed reactive hyperplasia and one left sided inguinal lymph node showed metastatic adenocarcinoma (1/9). The staging was ascertained as stage III. Immunohistochemistry was not done due to logistic issues.

Tumour board decision was adjuvant chemotherapy with radiotherapy. She received adjuvant chemotherapy regimen with cisplatin with paclitaxel every 3 weeks for 6 cycles. Post chemotherapy, removal of the catheter was tried, but she still remained incontinent. Decision was taken to retain the catheter. She then received adjuvant External Beam Radiotherapy (EBRT) of 50Gy in 25 fractions to pelvis in Linear Accelerator 6MV by conformal planning with Intensity-Modulated Radiation Therapy (IMRT). After the radiotherapy was completed, on removing the catheter she became continent again with no surgical intervention. She has been disease free till date and survival period of 36 months since the time of diagnosis.

Incidentally her 35-year-old daughter, was diagnosed with a complex ovarian mass while her mother was undergoing treatment at our institute. Her CA125 was $1931 \mathrm{IU} / \mathrm{ml}$. She underwent laparotomy followed by total abdominal hysterectomy and bilateral salpingo-oophorectomy and Infra-colic Omentectomy. Intraoperatively, the mass was diagnosed as a $10 \mathrm{~cm} \mathrm{x}$ $10 \mathrm{~cm}$ endometrioma. Histopathology revealed Ovarian Endometriotic cyst with focal areas of dysplasia (Immunohistochemistry - benign). She is under followup at present.

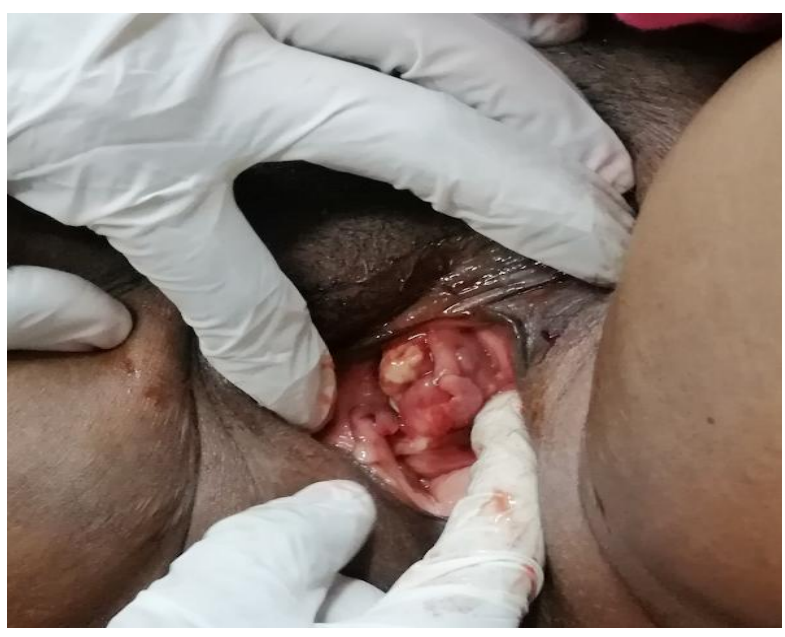

Fig-1: Clinical presentation 


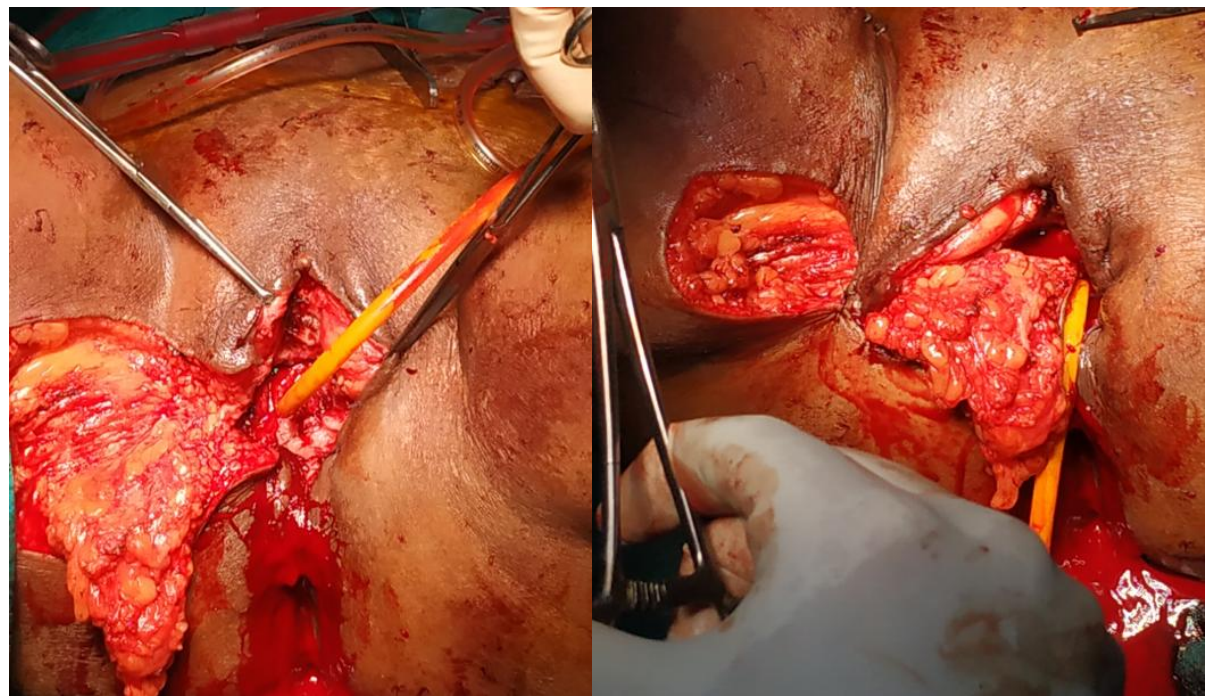

Fig-2: Intraoperative pictures: Vulvectomy followed by lotus flap reconstruction

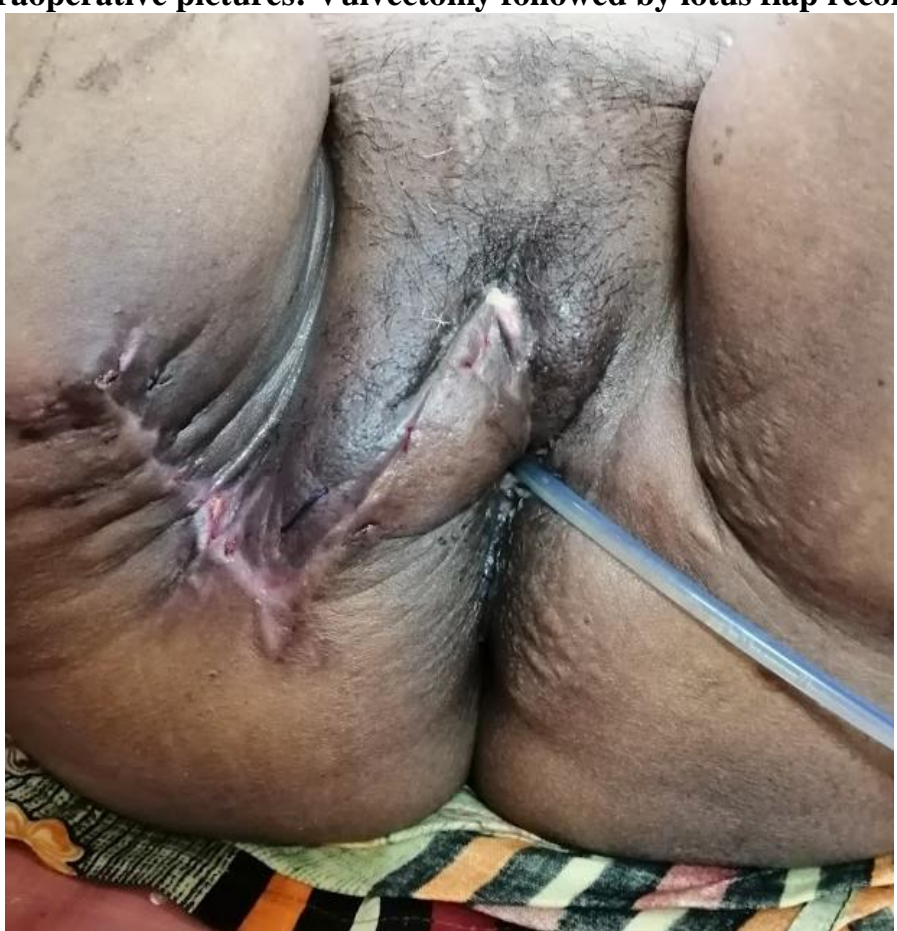

Fig-3: Postoperative day 21

Table-1: Literature review of previously reported cases of PVCAA

\begin{tabular}{|c|c|c|c|c|c|c|c|c|c|c|}
\hline & Reported by & Age & $\begin{array}{l}\text { Vaginal } \\
\text { adenosis }\end{array}$ & $\begin{array}{l}\text { Mullerian } \\
\text { anomalies }\end{array}$ & DES & Surgery & Radiotherapy & Chemotherapy & Stage & $\begin{array}{l}\text { Disease } \\
\text { free } \\
\text { Survival }\end{array}$ \\
\hline 1 & $\begin{array}{l}\text { Uehara T et } \\
\text { al., } 2010\end{array}$ & 54 & No & Yes & No & $\begin{array}{l}\text { Anterior pelvic } \\
\text { exenteration }\end{array}$ & No & No & I & $\begin{array}{l}43 \\
\text { months }\end{array}$ \\
\hline 2 & $\begin{array}{l}\text { Zeeshan-ud- } \\
\text { din et al., } \\
2009\end{array}$ & 27 & No & Yes & No & $\begin{array}{l}\text { Wertheim's } \\
\text { hysterectomy+ } \\
\text { partial vaginectomy } \\
\text { + pelvic lymph node } \\
\text { dissection }\end{array}$ & Not Mentioned & Not Mentioned & III & $\begin{array}{l}\text { Not } \\
\text { reported }\end{array}$ \\
\hline 3 & $\begin{array}{l}\text { Bhattacharya } \\
\text { et al., } 2016\end{array}$ & 45 & No & Yes & No & $\begin{array}{l}\text { Hysterectomy }+ \\
\text { removal of pelvic } \\
\text { lymph nodes. }\end{array}$ & None & None & I & 2 months \\
\hline 4 & $\begin{array}{l}\text { Sachan et al., } \\
2013\end{array}$ & 27 & No & No & No & $\begin{array}{l}\text { Radical } \\
\text { hysterectomy + } \\
\text { vaginectomy + } \\
\text { lymph node } \\
\text { dissection }\end{array}$ & No & No & I & $\begin{array}{l}\text { Not } \\
\text { reported }\end{array}$ \\
\hline
\end{tabular}


Puja Chatterjee et al., Sch J Med Case Rep, Apr, 2021; 9(4): 393-397

\begin{tabular}{|c|c|c|c|c|c|c|c|c|c|c|}
\hline & Reported by & Age & $\begin{array}{l}\text { Vaginal } \\
\text { adenosis }\end{array}$ & $\begin{array}{l}\text { Mullerian } \\
\text { anomalies }\end{array}$ & DES & Surgery & Radiotherapy & Chemotherapy & Stage & $\begin{array}{l}\text { Disease } \\
\text { free } \\
\text { Survival }\end{array}$ \\
\hline 5 & $\begin{array}{l}\text { Mufti et al } \\
2014\end{array}$ & 9 & No & No & No & Surgical resection & No & No & IVB & $\begin{array}{l}\text { Died } \\
\text { shortly } \\
\text { after } \\
\text { surgery }\end{array}$ \\
\hline 6 & $\begin{array}{l}\text { Mufti et al } \\
2014\end{array}$ & 27 & No & No & No & $\begin{array}{l}\text { Neoadjuvant } \\
\text { radiotherapy } \\
\text { followed by } \\
\text { hysterectomy }\end{array}$ & Neoadjuvant & No & III & $\begin{array}{l}24 \\
\text { months }\end{array}$ \\
\hline 7 & $\begin{array}{l}\text { Hasanzadeh } \\
\text { et al., } 2019\end{array}$ & 49 & No & No & No & $\begin{array}{l}\text { Radical } \\
\text { hysterectomy with } \\
\text { excision of } \sim 4 \mathrm{~cm} \\
\text { of the vaginal wall + } \\
\text { bilateral } \\
\text { oophorectomy } \\
\text { +pelvic and } \\
\text { paraaortic lymph } \\
\text { node dissection }\end{array}$ & $\begin{array}{l}\text { Concurrent } \\
\text { Chemoradiother } \\
\text { apy }\end{array}$ & No & III & $\begin{array}{l}10 \\
\text { months }\end{array}$ \\
\hline 8 & $\begin{array}{l}\text { Pang et al., } \\
2019\end{array}$ & 45 & Yes & No & No & wide local resection & No & No & I & $\begin{array}{l}\text { 20month } \\
\mathrm{s}\end{array}$ \\
\hline 9 & $\begin{array}{l}\text { Mei et al., } \\
2020\end{array}$ & 41 & No & Yes & No & $\begin{array}{l}\text { Radical } \\
\text { hysterectomy, } \\
\text { bilateral salpingo- } \\
\text { oophorectomy, and } \\
\text { pelvic } \\
\text { lymphadenectomy }\end{array}$ & No & No & $\mathrm{I}$ & $\begin{array}{l}17 \\
\text { months }\end{array}$ \\
\hline 10 & $\begin{array}{l}\text { Güzin et al., } \\
2006\end{array}$ & 23 & No & No & No & No & Yes & Yes & II & $\begin{array}{l}14 \\
\text { months }\end{array}$ \\
\hline 11 & $\begin{array}{l}\text { Cello et al., } \\
2019\end{array}$ & 28 & No & Yes & No & $\begin{array}{l}\text { Oocyte } \\
\text { cryopreservation > } \\
\text { laparoscopic pelvic } \\
\text { lymphadenectomy. } \\
\text { Uterus, tubes, and } \\
\text { ovaries preserved. } \\
\text { Wide local excision } \\
\text { of vagina with } \\
\text { resection of septum }\end{array}$ & Yes & No & $\mathrm{I}$ & $\begin{array}{l}\text { 60month } \\
\mathrm{s}\end{array}$ \\
\hline 12. & $\begin{array}{l}\text { Watanabe } e t \\
\text { al., } 2000\end{array}$ & 63 & No & No & No & No & No & No & IV B & 1 month \\
\hline
\end{tabular}

\section{Discussion/ CONCLUSION}

The tumour board faced difficulty in coming to an agreement regarding the extent of surgery and requirement of adjuvant chemotherapy, however the decision for adjuvant radiotherapy was unanimous. Review of literature shows that surgery is the mainstay of treatment for early localised disease however there is disparity in the type of surgery performed, ranging from anterior exenteration, radical hysterectomy to wide local excision (Table-1). There was no consensus regarding pelvic or inguinal lymph node dissections. Adjuvant radiotherapy is recommended for the cases which more than stage $\mathrm{I}$ at the time of diagnosis. Adjuvant chemotherapy was used in only one of the patients out of the 12 analysed case reports [1-12].

Vaginal adenosis is associated with PVCCA in 90\% cases, suggesting adenosis to be a precursor lesion [3]. In retrospective study, it was found that $69.4 \%$ of the analysed patients with genitourinary tract malformations had adenocarcinoma of the lower genital tract [13]. This suggested that genitourinary anomalies were associated with an increased risk of adenocarcinoma, but the mechanism was not clear. There is no definite history of DES exposure in this patient. There was no evidence of vaginal adenosis or any Mullerian anomalies in this case.

Frank et al assessed the outcomes of 26 patients with Primary non-DES-associated adenocarcinoma of the vagina (NDAV) and compared with it with patients with squamous cell carcinoma (SCC) of the vagina treated similarly over the same period. At 5 years, the overall survival rates of patients with NDAV and SCC were $34 \%$ and 58\%, respectively $(\mathrm{p}<0.01)$. Patients with NDAV had a significantly worse pelvic disease control rate than patients with SCC ( $31 \%$ vs. $81 \%$; p $<0.01$ ). At 5 years, $39 \%$ of patients with NDAV and 15\% with SCC had developed distant metastasis $(\mathrm{p}<0.01)$ [14]. Tanaka et al., concluded that the 5-year survival rates were $91 \%, 80 \%, 37 \%$, and $0 \%$ for stages 1,2,3, and 4 tumours in PVCCA respectively [15].

Conflict of Interest Statement: None

Funding Sources: None

Compliance with Ethical Standards

- Disclosure of potential conflicts of interest- None 
- Research involving Human Participants and/or Animals- The patient received standard of care treatment

- Informed consent- Informed consent from the patient was obtained before preparing the manuscript.

\section{REFERENCES}

1. Mahdavi A, Shamshirsaz AA, Peiretti M, Zakashansky K, Idrees MT, Nezhat F. Laparoscopic management of vaginal clear cell adenocarcinoma arising in pelvic endometriosis: case report and literature review. J Minim Invasive Gynecol. 2006;13(3):237-241.

2. Zeeshan-ud-din, Ahsan A. Vaginal clear cell adenocarcinoma with associated Müllerian duct anomalies, renal agenesis and situs inversus: report of a case with no known in-utero exposure with diethyl stilboestrol. J Pak Med Assoc. 2009 Aug;59(8):568-70. PMID: 19757709.

3. Uehara T, Onda T, Sasajima Y, Sawada M, Kasamatsu T. A case of vaginal clear cell adenocarcinoma complicated with congenital anomalies of the genitourinary tract and metanephric remnant without prenatal diethylstilbestrol exposure. J Obstet Gynaecol Res. 2010;36(3):681-685.

4. Bhattacharya S, Dasgupta S, Pramanik S, Ghosh P. Primary clear cell adenocarcinoma of vagina - not associated with diethylstilbestrol exposure. Int $\mathbf{J}$ Reprod Contracept Obstet Gynecol. 2016;5:4061-3.

5. Sachan R, Gupta P, Patel ML. Clear cell adenocarcinoma of vagina associated with uterine prolapse: A rare entity. International Journal of Case Reports and Images 2013;4(3):154-157.

6. Mufti ST, Ali HH. Non-diethylstilbestrolassociated primary clear cell carcinoma of the vagina: two case reports with immunohistochemical studies and literature review. Iran J Med Sci. 2014;39(3):298-303.

7. Hasanzadeh, M., Jafarian, A., Mousavi Seresht, L. Primary Clear Cell Carcinoma with no Diethylstilbestrol Exposure; Case Series. Iranian Journal of Medical Sciences, 2019; 44(2): 163-167. doi: 10.30476/ijms.2019.44517
8. Pang L, Li L, Zhu L, Lang J, Bi Y. Malignant transformation of vaginal adenosis to clear cell carcinoma without prenatal diethylstilbestrol exposure: a case report and literature review. BMC Cancer. 2019 Aug 13;19(1):798. doi: 10.1186/s12885-019-6026-1. PMID: 31409310; PMCID: PMC6693164.

9. Mei L, Zou J, Chen Q, Jiang W, Chen Y. Primary vaginal clear cell adenocarcinoma accompanied by Herlyn-Werner-Wunderlich syndrome without prenatal diethylstilbestrol exposure: a case report. Int J Clin Exp Pathol. 2020 Nov 1;13(11):27842787.

10. Güzin K, Eser SK, Yiğit A, Zemheri E. Primary clear cell carcinoma of the vagina that is not related to in utero diethylstilbestrol use. Gynecological Surgery. 2006 Dec;3(4):281-4.

11. Di Cello, F. Visconti, P. Quaresima, G. Bitonti, F. Zullo. Vaginal clear cell adenocarcinoma in a young woman with a Müllerian duct anomaly and no history of in utero diethylstilbestrol exposure: a fertility-sparing approach. European Journal of Gynaecological Oncology, 2019, 40(2):334-336.

12. Watanabe $\mathrm{Y}$, Ueda $\mathrm{H}$, Nozaki K, Kyoda A, Nakajima H, Hoshiai H, Noda K. Advanced primary clear cell carcinoma of the vagina not associated with diethylstilbestrol. Acta Cytol. 2002 May-Jun;46(3):577-81.

13. Zong L, Wang W, He Y, Cheng N, Xiang Y. Carcinoma of the lower female genital tract in patients with genitourinary malformations: a clinicopathologic analysis of 36 cases. J Cancer. 2019;10:3054-3061.

14. Frank SJ, Deavers MT, Jhingran A, Bodurka DC, Eifel PJ. Primary adenocarcinoma of the vagina not associated with diethylstilbestrol (DES) exposure. Gynecol Oncol. 2007 May;105(2):470-4.

15. Tanaka $H$, Tabata $T$, Yanase $H$, Nishiyama $M$, Yamawaki T, Taniguchi H, Toyoda N. Clear cell adenocarcinoma of the vagina in a young female, treated by combination chemotherapy (local and systemic chemotherapy), complicated with chromosomal abnormality. Gynecologic oncology. 1994 Nov 1;55(2):259-64. 